\title{
Application of UAV-SfM photogrammetry and aerial lidar to a disastrous flood: repeated topographic measurement of a newly formed crevasse splay of the Kinu River, central Japan
}

\author{
Atsuto Izumida ${ }^{1}$, Shoichiro Uchiyama ${ }^{1,2}$, and Toshihiko Sugai ${ }^{1}$ \\ ${ }^{1}$ Graduate School of Frontier Sciences, the University of Tokyo, Kashiwa, Chiba 277-8563, Japan \\ ${ }^{2}$ National Research Institute for Earth Science and Disaster Prevention, Tsukuba, Ibaraki 305-0006, Japan \\ Correspondence to: Atsuto Izumida (aizumida@s.nenv.k.u-tokyo.ac.jp)
}

Received: 31 January 2017 - Discussion started: 2 February 2017

Revised: 28 July 2017 - Accepted: 9 August 2017 - Published: 13 September 2017

\begin{abstract}
Geomorphic impacts of a disastrous crevasse splay that formed in September 2015 and its post-formation modifications were quantitatively documented by using repeated, high-definition digital surface models (DSMs) of an inhabited and cultivated floodplain of the Kinu River, central Japan. The DSMs were based on pre-flood (resolution: $2 \mathrm{~m}$ ) and post-flood (resolution: $1 \mathrm{~m}$ ) aerial light detection and ranging (lidar) data from January 2007 and September 2015, respectively, and on structure-from-motion (SfM) photogrammetry data (resolution: $3.84 \mathrm{~cm}$ ) derived from aerial photos taken by an unmanned aerial vehicle (UAV) in December 2015. After elimination of systematic errors among the DSMs and down-sampling of the SfM-derived DSM, elevation changes on the order of $10^{-1} \mathrm{~m}$ - including not only topography but also growth of vegetation, vanishing of flood waters, and restoration and repair works - were detected. Comparison of the DSMs showed that the volume eroded by the flood was more than twice the deposited volume in the area within $300-500 \mathrm{~m}$ of the breached artificial levee, where the topography was significantly affected. The results suggest that DSMs based on a combination of UAV-SfM and lidar data can be used to quantify, rapidly and in rich detail, topographic changes on floodplains caused by floods.
\end{abstract}

\section{Introduction}

Floods are becoming increasingly serious natural disasters as more and more people move themselves and their assets into flood-prone areas (Berz et al., 2001; Barredo, 2007;
Kundzewicz et al., 2010). Present-day levee breaches along rivers under human control create landforms quite different from and, in some cases, much larger than those created by levee breaches along natural rivers, because of houses and paved streets, which control the distribution of sand lobes by acting as channels for flood flow (Nelson and Leclair, 2006), and because the construction of artificial levees raises the potential energy of the flood waters (Gebica and Sokolowski, 2001). It is important to determine the volume and area of erosion or deposition that can be expected to occur and how the topographic changes are likely to be distributed on a floodplain during high-magnitude flood events, because these factors directly determine the magnitude and extent of the damage that can be expected to result from a disastrous flood event.

Recently, high-resolution topographic data acquired by innovative remote-sensing methods such as aerial and terrestrial light detection and ranging (lidar) and structure-frommotion (SfM) photogrammetry have been widely used to evaluate the magnitude of natural hazards (Tarolli, 2014; Gomez and Purdie, 2016). In particular, the combination of SfM with aerial photographs acquired by unmanned aerial vehicles (UAVs) can be very useful in hazardous areas subject to natural disasters such as earthquakes, volcanic eruptions, and landslides, because of the low-cost and mobile operation of UAVs (Gomez and Purdie, 2016).

However, few quantitative descriptions of topography specifically related to a flood disaster on a floodplain are based on high-resolution topographic data obtained by using such methods. Wierzbicki et al. (2013) used post-flood 
aerial lidar data to capture a newly formed crevasse splay of the Vistula River, Poland, but they did not have any pre-flood data to use for topographic comparison. The UAV-based SfM photogrammetric method (UAV-SfM) has basically not been used to examine floodplain topography in the context of a natural disaster, although Tamminga et al. (2015b) used it in a fluvial setting to characterize the morphology of a gravelbed river.

Although several studies have performed hydraulic analyses following a large flood, such as floodwater mapping in urban areas (Feng et al., 2015) and basin-scale sediment budget estimation (Croke et al., 2013), floodplain topography has attracted less attention from researchers. Reasons may include the low relief and urban or agricultural land uses of floodplains (Ninfo et al., 2016) and the low preservation potential of flood-related topography in urban areas (Nelson and Leclair, 2006). Moreover, in many cases, reliable topographic data before a flood event, allowing the investigation of topographic changes, are not available, which prevents detailed quantification of flood-caused topographic changes (Tamminga et al., 2015a).

In this study, we used high-resolution topographic data sets to deal with these difficulties and studied topographic changes caused by a disastrous flood that occurred along the Kinu River, central Japan, in 2015. In the study area, this flood caused a crevasse splay to form on an inhabited and cultivated floodplain. Three digital surface models (DSMs) of the research area were generated by aerial lidar and UAV-SfM: before, 3 days after, and 3 months after the flood. The features and post-flood modification of the topography caused by a levee breach were then quantitatively documented from the perspective of both natural and artificial changes. In addition, volume calculations were conducted using these DSMs to investigate the balance between deposition and erosion processes during the flood, and the volumetric extent of the post-flood restoration works in the breached artificial levee and intensively eroded areas.

\section{Study area}

The Kinu River, $177 \mathrm{~km}$ long with a catchment area of $1760 \mathrm{~km}^{2}$ in central Japan, originates in the mountains north of the Kanto region and joins the Tone River in the central Kanto Plain (Fig. 1). Neogene and Quaternary volcanic rocks are complexly distributed in the mountains that occupy $60 \%$ of its catchment area. The rest of the catchment is on the Kanto Plain, where the present floodplain and Pleistocene fluvial terraces are dominant. Mean annual precipitation is $1600-2100 \mathrm{~mm}$ in the mountains and $1300-1500 \mathrm{~mm}$ on the plain.

The area affected by the 2015 flood is located about $20 \mathrm{~km}$ upstream of the Kinu River's confluence with the Tone River (Fig. 1). The Kinu River in this area has low sinuosity and a sandy bed with a gradient of about $1 / 2500$, flowing south- ward. The Kinu River and the Kokai River, another tributary of the Tone River, flow along the western and eastern margin of the floodplain, respectively. These rivers and their abandoned channels are surrounded by alluvial ridges $1-2 \mathrm{~m}$ higher than flood basin. The largest alluvial ridges, which are $1.5-2 \mathrm{~km}$ wide, are those to the east of the Kinu River. The alluvial ridges in this floodplain are densely inhabited, and most villages are located on them. Other parts of the alluvial ridges are used as agricultural lands, predominantly paddy fields. Irrigation canals provide water to the entire floodplain, and almost all of the floodplain area is used for paddy fields.

The research area covered by the DSMs is in the southern part of a $1.5 \mathrm{~km}$-wide alluvial ridge along the Kinu River (Fig. 1). Within the research area, the elevation of the ridge is high along the channel, especially near the breached levee, although the ground level there might have been raised for construction. The artificial levee is about $2 \mathrm{~m}$ higher than the top of the alluvial ridge. The alluvial ridge is divided by a shallow valley oriented north-south along the eastern margin of the study area, which has been inferred to be a past crevasse channel (Sadakata, 1971). At present, an agricultural canal runs along the valley, and a network of smaller canals covers the research area. The part of the alluvial ridge in the study area is mainly used for cultivating agricultural crops; most of the area is not covered by pavement or buildings except close to the levee.

Repeated flooding of the Kinu and Kokai rivers around the study area during the past several hundred years is documented in the historical record, although how each flood affected the topography of the floodplain is unclear. Two floods occurred recently along the Kokai River, in 1981 and 1986. At a point $4 \mathrm{~km}$ upstream of its confluence with the Tone River, where the Kokai River intersected an abandoned channel, a crevasse splay was formed during the 1981 flood that created a sandy mound more than $60 \mathrm{~cm}$ thick and a crevasse channel (breach scouring) with a length of $200 \mathrm{~m}$ and a depth of $2 \mathrm{~m}$ (Iseya et al., 1982).

\section{The 2015 flood of the Kinu River}

A levee breach of the Kinu River in the city of Joso, Ibaraki Prefecture, which occurred on 10 September 2015, was caused by a record heavy rain during 7-11 September, particularly during 9-10 September, driven by Typhoon Etau and the extratropical cyclone it became. The total rainfall during the period of heavy rain exceeded $600 \mathrm{~mm}$ along the upper reaches of the Kinu River and 200-300 mm along the central to lower reaches (Japan Meteorological Agency, 2015). Statistical analysis by Yoshimura (2016) suggests that the return times of the 1-day, 2-day, and 3-day cumulative rainfall of the 2015 flood over the drainage area of the Kinu River are 95,138 , and 237 years, respectively. At a gauge station located $10 \mathrm{~km}$ upstream from the breached levee, the peak water level, which was more than $6 \mathrm{~m}$ higher than the ordi- 


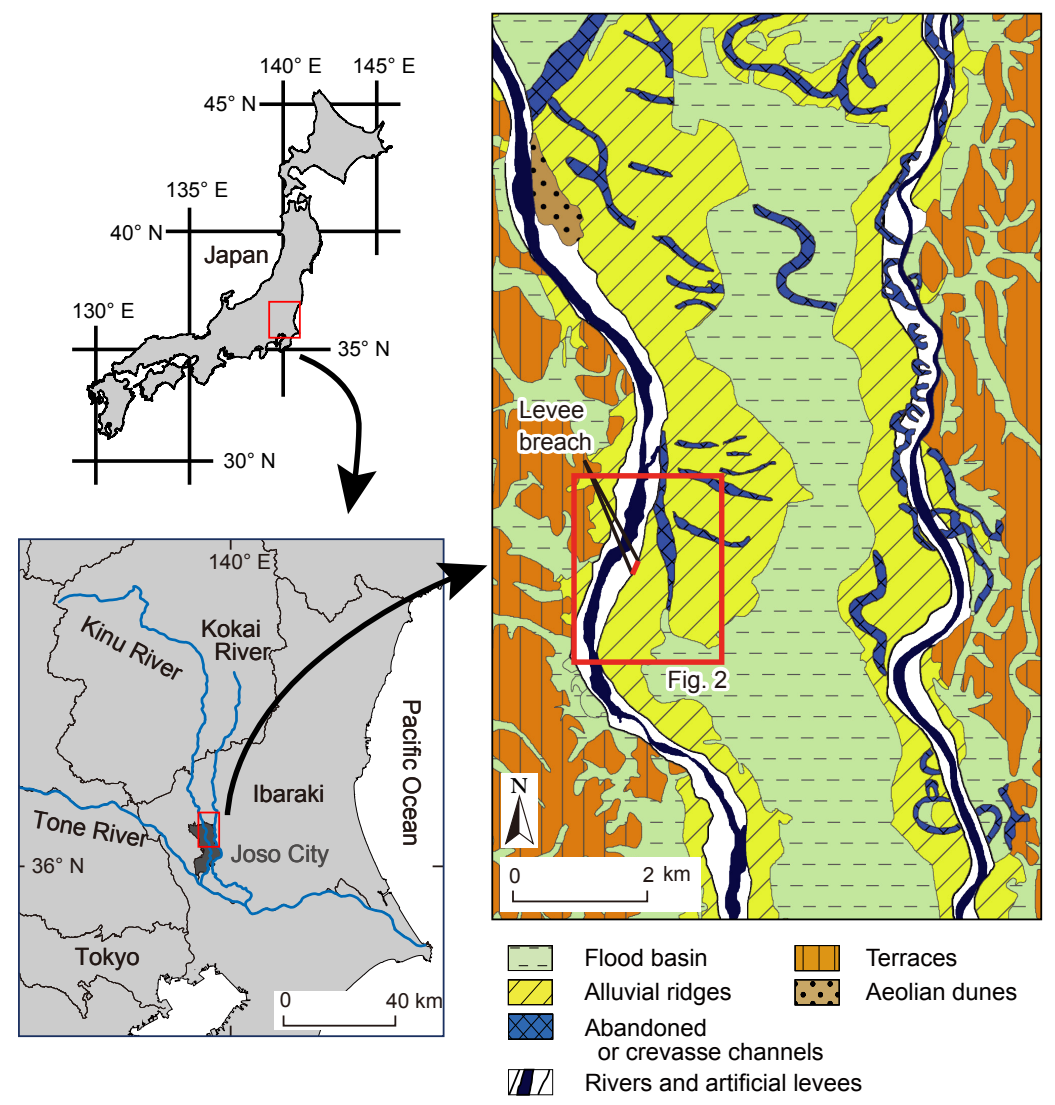

Figure 1. Location map of the city of Joso and the Kinu River, and geomorphic map showing the location of the levee breached during the 2015 flood.

nary water level, was recorded on 10 September. KinugawaMitsukaido gauge station, which is $10 \mathrm{~km}$ downstream of the breached point of the Kinu River, marked a peak discharge of ca. $4000 \mathrm{~m}^{3} \mathrm{~s}^{-1}$, which was the maximum observed in the previous 90 years, and during that period a similar discharge (ca. $3900 \mathrm{~m}^{3} \mathrm{~s}^{-1}$ ) was observed there only once, in 1949 (Kanto Regional Development Bureau, Ministry of Land, Infrastructure, Transport and Tourism, 2015).

The levee breach and other outflows from the Kinu River that occurred on 10 September inundated an area of $40 \mathrm{~km}^{2}$ on the floodplain between the Kinu and Kokai rivers; this area is equivalent to one-third of the area of Joso. The flood water reached a depth of more than $2.5 \mathrm{~m}$ in the flood basin; the inundation depth of the alluvial ridges was generally $1 \mathrm{~m}$ or less near the breached levee, whereas the depth increased to $1.5 \mathrm{~m}$ or more in the southern part of the floodplain and decreased to between 0.5 and $0 \mathrm{~m}$ far from the breached levee (Nagumo et al., 2016). The flood caused two deaths, injured 44, and forced the evacuation of 6000 of the 65000 inhabitants of Joso, and it damaged, destroyed, or inundated 5000 buildings (Joso City, 2016). The breached levee had been temporarily repaired by 2 weeks after the flood, thus preventing additional flooding of the Kinu River (Kanto Regional Development Bureau, Ministry of Land, In- frastructure, Transport and Tourism, 2015). The economic loss due to the flood and rainfall has been estimated to be JPY 294.1 billion for the entire flood disaster in September 2015 (Ministry of Land, Infrastructure, Transport and Tourism Japan, 2017).

\section{Method}

\subsection{Data acquisition and DSM generation}

\subsubsection{Lidar data}

Two sets of lidar measurement data - acquired on 15 January 2007, before the flood, and on 13 September 2015, 3 days after the flood - were used in this study. Land use in the study area is mainly agricultural (cultivated land), except for the area next to the levee, and the land was largely bare of vegetation because it was winter when the first data set was acquired. Moreover, when the second data set was acquired immediately after the flood, the crops had been almost flattened by the flood waters. Thus, both data sets are considered to represent fairly clean bare land, without any adjustment for surface objects such as vegetation and buildings being 
needed. These data sets also include georeferenced orthophotos.

Lidar data before the flood were provided by the Kanto Regional Development Bureau, Ministry of Land, Infrastructure, Transport and Tourism. The measurement point density was 1.2 points $\mathrm{m}^{-1}$ in the east-west direction and 1.3 points $\mathrm{m}^{-1}$ in the north-south direction. The pixel size of the DSM was set to $2 \mathrm{~m}$, so each pixel contained two measurement points on average. We generated a DSM from these data by using the 3-D Analyst extension of ESRI ArcGIS 10.2.2 Desktop software. The Create TIN tool was first used to construct a triangular irregular network (TIN) of the data, and then the TIN was converted to a DSM by using the TINto-Raster tool.

Lidar data were acquired soon after the flood by Aero Asahi Corp. (AAC). The measurement point density was 0.43 points $\mathrm{m}^{-1}$. These lidar data were converted to raster data, and a DSM was generated by AAC by the TIN method, with the pixel size set to $1 \mathrm{~m}$. When the lidar data in September 2015 were acquired, some areas (mostly erosional zones) were inundated by floodwaters. However, laser scanning data could still be obtained with the same density in such inundated areas, probably because the muddy water was able to reflect the laser beams. The elevation of the inundated areas was interpolated to a grid in the same way as the non-inundated areas (TIN method). It should be noted that whether or not the laser beams reflected strictly from the water surface was not confirmed. In this study, however, they were regarded as indicating the elevation of the water surface because the elevation of continuous water bodies showed little fluctuation and matched that of the ground at the edge of the water.

During the lidar measurement, the position of the aircraft was determined by kinematic GNSS equipment, and the inclination of the aircraft (roll, pitch, and yaw) was logged by an inertial measurement unit. The onboard position information was improved by post-processing using ground reference stations maintained by the Geospatial Authority of Japan, established by a static GNSS survey.

\subsubsection{UAV-SfM data}

On 26 December 2015, we conducted a flight campaign with a UAV (DJI F550 six-rotor multicopter equipped with an ArduPilot Mega 2.6, UAV flight controller by 3DR) over the alluvial ridge where significant topographic changes had been caused by the flood to obtain high-resolution measurements and to characterize the post-formation modifications of the crevasse splay. The flight was automatically piloted by a Mission Planner ground station; the UAV's height was maintained at $150 \mathrm{~m}$ above ground level, and its speed was maintained at $10 \mathrm{~m} \mathrm{~s}^{-1}$ while the photographs were being acquired. The UAV was equipped with a Ricoh GR digital camera (focal length: $18.3 \mathrm{~mm}$; resolution: 16.2 megapixels) and weighed about $2.4 \mathrm{~kg}$ altogether. Six flights, each $15 \mathrm{~min}$

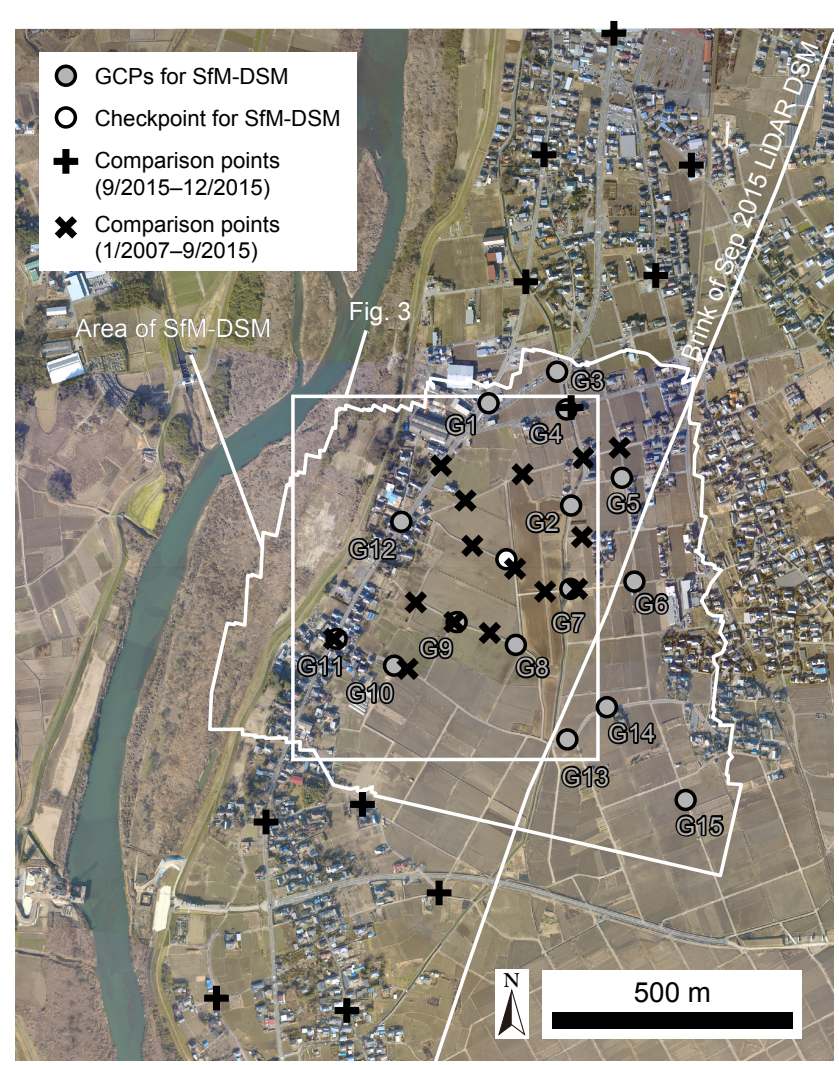

Figure 2. Distributions of GCPs and checkpoints for the SfMderived DSM and comparison points for each DSM subtraction pair.

long, were conducted over $2 \mathrm{~h}$ on the morning of 26 December, and 597 photos were taken at $2 \mathrm{~s}$ intervals with an $80 \%$ overlap both across and along the UAV paths. The camera was flexibly held by a Picavet suspension system (see Inoue et al., 2014) so that the off-nadir angle of each photo differed slightly within a range of $10-15^{\circ}$ in the backward direction.

We used Agisoft PhotoScan Pro 1.2.1 software for automatic camera calibration and the SfM analysis. The DSM was georeferenced by 15 ground control points (GCPs) obtained by a real-time kinematic GNSS using a Trimble Geo 7X instrument and Zephyr Model 2 antenna with a horizontal and vertical accuracy of $5 \mathrm{~cm}$ (Fig. 2). Flat places with low relief such as a paved road were selected for the GCP locations so that local relief and objects would not affect the elevation of the pixels around the GCPs. The ground resolution of the resulting DSM was $3.84 \mathrm{~cm}$, and it covered an area of about $0.793 \mathrm{~km}^{2}$. The root mean square error (RMSE) of the DSM with 15 GCPs was $2.37 \mathrm{~cm}$ in the east-west direction, $2.14 \mathrm{~cm}$ in the north-south direction, $1.58 \mathrm{~cm}$ vertically, and $3.56 \mathrm{~cm}$ overall (Table 1). The reprojection error was 0.46 pixel, which is no larger than that of a similar SfM analysis with images taken by UAV (Pineux et al., 2016).

The doming effect is a fundamental problem of DSM generation by SfM analysis associated with near-parallel image 


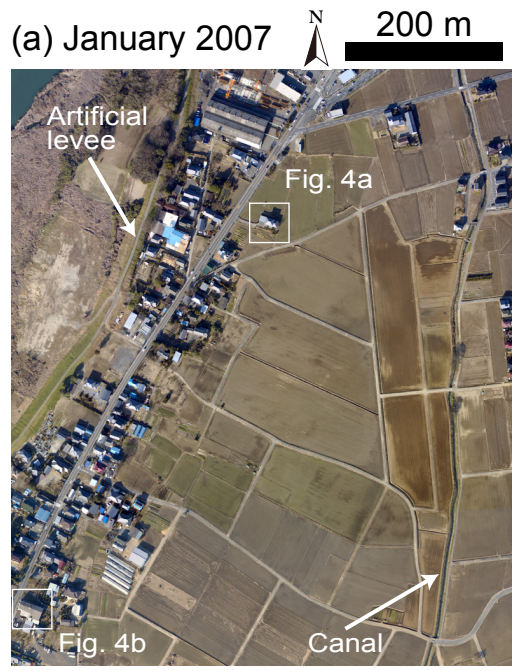

(b) September 2015
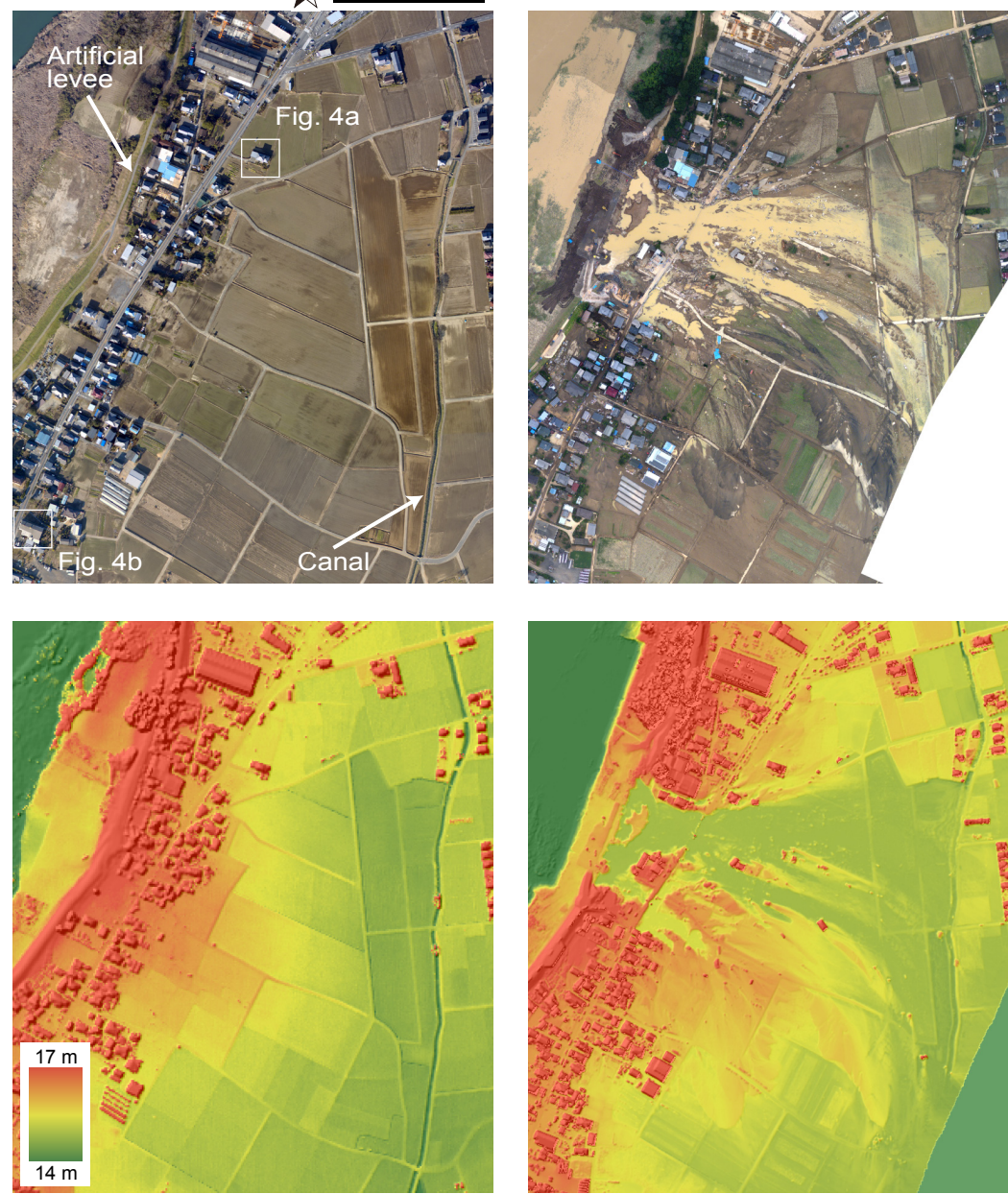

(c) December 2015
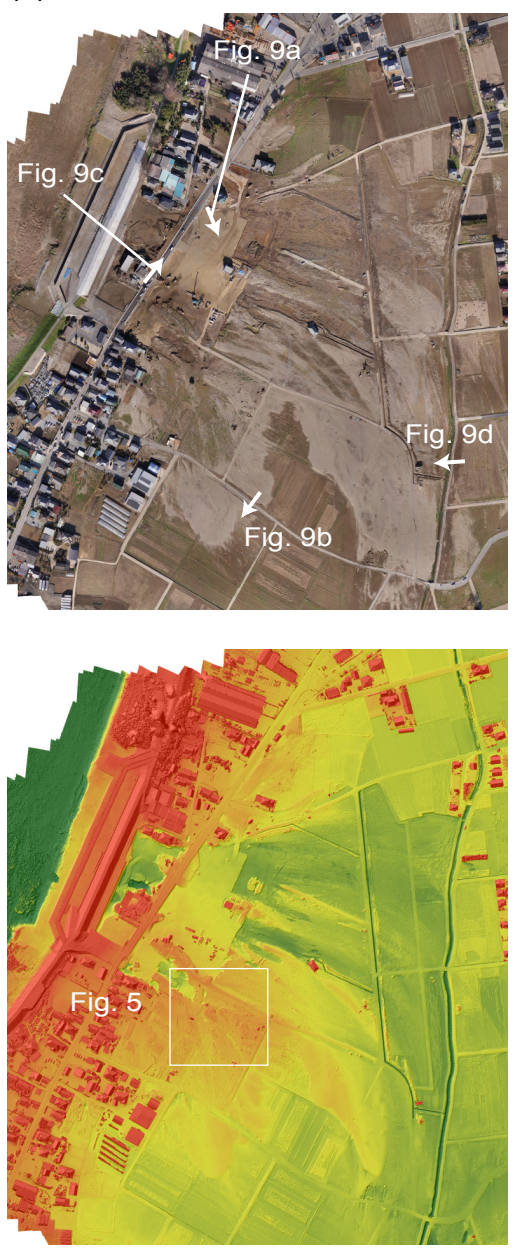

Figure 3. The three orthophotos (top) and DSMs (bottom) used in this study. See the text for information about the acquisition of each data set. Elevations are relative to mean sea level in Tokyo Bay. Note that the research area does not correspond to the areas of these DSMs.

sets and inaccurate correction of radial lens distortion (James and Robson, 2014). The image acquisition method used in this study included several techniques to mitigate doming of the SfM-derived DSM: a high overlap rate of the images, precisely and widely placed GCPs, and varying off-nadir angles. The error of each GCP between the GNSS measurement and the derived model was less than $5 \mathrm{~cm}$, the same as the accuracy of the GNSS measurement, except for one GCP located at the edge of the DSM. In addition, a checkpoint obtained by the same GNSS measurement showed an error of $0.56 \mathrm{~cm}$ against the SfM-derived DSM (Fig. 2). Although the result of the camera calibration was not quantitatively tested, these numbers suggest that the doming effect of the SfM-derived DSM was sufficiently small to enable comparison with other lidar DSMs.

\subsection{Evaluation of the horizontal accuracy of the DSMs}

To validate that an object was represented at the same location on all DSMs, each of which had been georeferenced independently, the gradient of each pixel was calculated for the three DSMs, and the edges of the same houses and other buildings were identified independently on the three gradient rasters (Fig. 4). The slope gradients of each rasters were calculated using the Slope tool of ArcGIS with the planar method. In Fig. 4, areas with high slope gradients are white, causing the boundaries between vertical structures such as buildings and walls or trees and the ground to appear as white belts. The lines indicating building edges and walls on the December 2015 gradient map are located in the center of the areas with high slope gradients on the DSMs for the other two dates. These areas are wide when the resolution of the original DSM is low; therefore, it is the resolution of the DSM, rather than its horizontal accuracy, that matters most when evaluating topographic changes by raster comparison. 
Table 1. Error of each ground control point (GCP) and RMSEs for all 15 GCPs in the SfM processing.

\begin{tabular}{lrrrr}
\hline GCP & $\begin{array}{r}X \text { error } \\
(\mathrm{cm})\end{array}$ & $\begin{array}{r}Y \text { error } \\
(\mathrm{cm})\end{array}$ & $\begin{array}{r}Z \text { error } \\
(\mathrm{cm})\end{array}$ & $\begin{array}{r}\text { Total error } \\
(\mathrm{cm})\end{array}$ \\
\hline G1 & -2.34 & 3.43 & -0.20 & 4.15 \\
G2 & 3.14 & -2.48 & 2.76 & 4.86 \\
G3 & -1.77 & -2.47 & -0.21 & 3.05 \\
G4 & -0.16 & -2.59 & 0.39 & 2.62 \\
G5 & 3.37 & 1.09 & -1.13 & 3.72 \\
G6 & 2.95 & 3.01 & 1.63 & 4.52 \\
G7 & 3.08 & -1.56 & -2.70 & 4.38 \\
G8 & 0.09 & 1.41 & 1.35 & 1.95 \\
G9 & -4.33 & -1.53 & -2.60 & 5.28 \\
G10 & -0.27 & 1.02 & 0.64 & 1.23 \\
G11 & -0.62 & -0.81 & 0.49 & 1.13 \\
G12 & 0.76 & -0.76 & -0.39 & 1.14 \\
G13 & -2.17 & 2.50 & 1.88 & 3.81 \\
G14 & -3.22 & -2.51 & -2.34 & 4.70 \\
G15 & 1.32 & 2.45 & 0.16 & 2.78 \\
RMSE & 2.37 & 2.14 & 1.58 & 3.56 \\
\hline
\end{tabular}

(a)
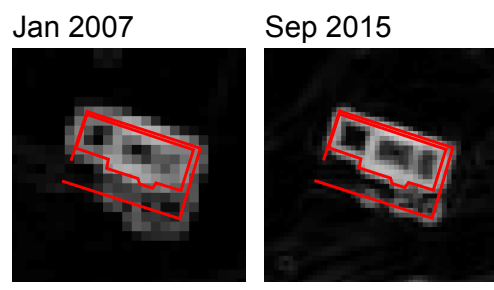

(b)
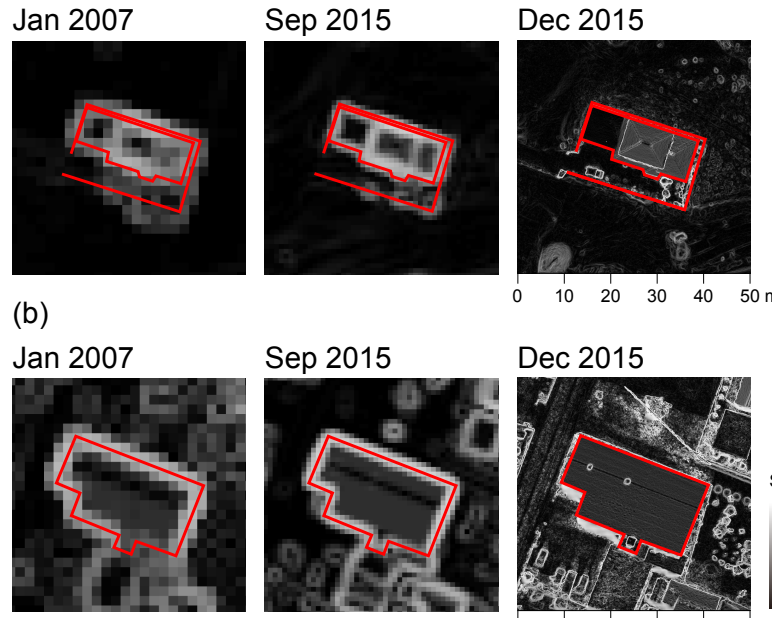

$\begin{array}{lll}10 & 20 \\ 0 & 30 & 0\end{array}$

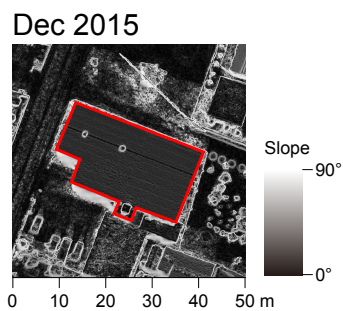

Figure 4. Gradient maps showing two buildings used to evaluate the horizontal accuracy of the DSMs. The cell sizes are the same as in the originals. Red lines indicate the edges of buildings or walls on the December 2015 map. Note that these lines are within highslope-gradient areas on the maps for the other two dates. See Fig. 3a for the locations.

\subsection{Calculation of differential rasters}

Raster subtraction of DSMs between successive dates allows the topographic changes occurring between the two dates to be evaluated. Comparison of the DSMs between the first two dates (before and soon after the flood) shows the direct impact of the flood on the topography of the floodplain, and comparison of the DSMs between the second two dates shows post-formation modification of the crevasse splay.
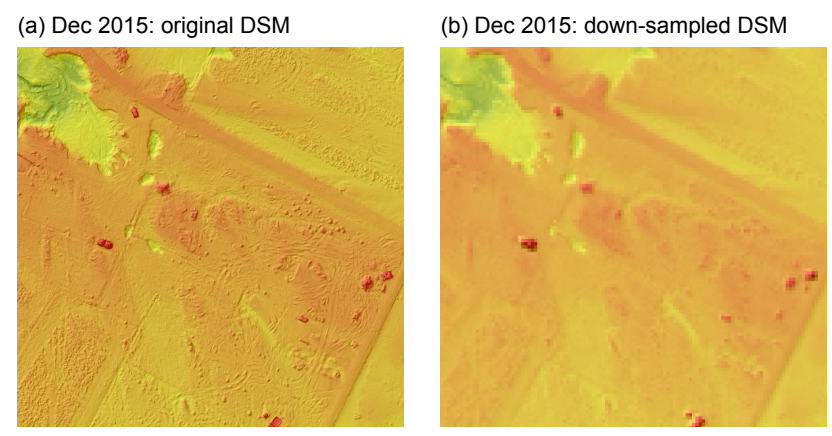

(c) Dec 2015: orthophoto

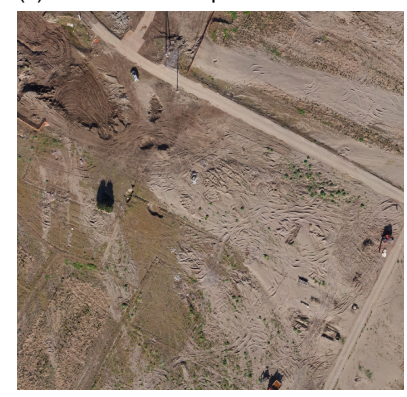

(d) Sep 2015: DSM

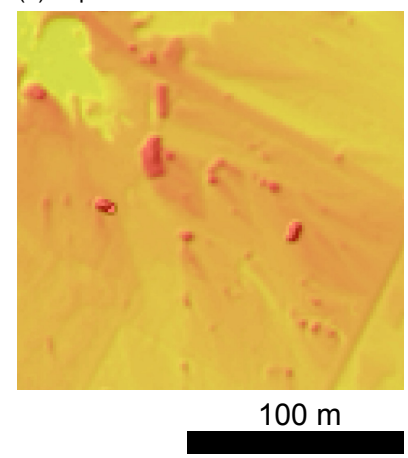

Figure 5. Enlarged views of Fig. 3 images for comparison of the DSMs with different resolutions. (a) Original DSM for December 2015 (resolution: $3.84 \mathrm{~cm}$ ). (b) Down-sampled DSM for December 2015 (resolution: $1 \mathrm{~m}$ ). (c) Orthophoto taken in December 2015. (d) DSM for September 2015 (resolution: $1 \mathrm{~m}$ ). Note that the trivial relief in (a) is largely removed in the down-sampled DSM in (b).

First, the resolution of the SfM-derived DSM was downsampled to $1 \mathrm{~m}$ to avoid local-scale effects that might be derived from trivial relief of the high-resolution surface model that was not represented in the DSMs with lower resolution (Fig. 5). The resolution and distribution of the pixels of the down-sampled DSM were set to be the same as those of the September 2015 DSM for definitive comparison of the two DSMs. Before the calculation of the differential rasters, it was necessary to evaluate the systematic errors between pairs of DSMs. The systematic error of each comparison set was determined by selecting more than 10 points at locations that were stable between the two dates and assigning the mean elevation difference at each of those points to the systematic error (Table 2). The selected comparison points were located in flat areas where little change was observed between the two dates and which were wider than the pixel sizes of the DSMs (Fig. 2).

The comparison results showed that elevations on the January 2007 DSM were higher than those on the September 2015 DSM by $37.9 \mathrm{~cm} \pm 4.5 \mathrm{~cm}$ (mean \pm standard deviation), and those on the September 2015 DSM were lower than those on the December 2015 DSM by $20.5 \mathrm{~cm} \pm 2.0 \mathrm{~cm}$. Then, the limit of detection (LoD) of elevation changes for each comparison pair was set to be the twice the standard de- 
Table 2. Points used to compare each pair of DSMs.

\begin{tabular}{llllll}
\hline Comparison pair & $\begin{array}{l}\text { Number of points } \\
\text { compared }\end{array}$ & $\begin{array}{l}\text { Maximum elevation } \\
\text { difference between } \\
\text { points }(\mathrm{cm})\end{array}$ & $\begin{array}{l}\text { Minimum elevation } \\
\text { difference between } \\
\text { points }(\mathrm{cm})\end{array}$ & $\begin{array}{l}\text { Mean elevation } \\
\text { difference between } \\
\text { points }(\mathrm{cm})\end{array}$ & $\begin{array}{l}\text { Standard deviation } \\
\text { of the difference } \\
\text { between points }(\mathrm{cm})\end{array}$ \\
\hline Jan 2007 and Sep 2015 & 11 & 45.9 & 28.8 & 37.9 & 4.5 \\
Sep 2015 and Dec 2015 & 15 & 23.1 & 15.7 & 20.6 & 1.8 \\
\hline
\end{tabular}

(a) January 2007 to September $2015(\sigma=4.5 \mathrm{~cm})$

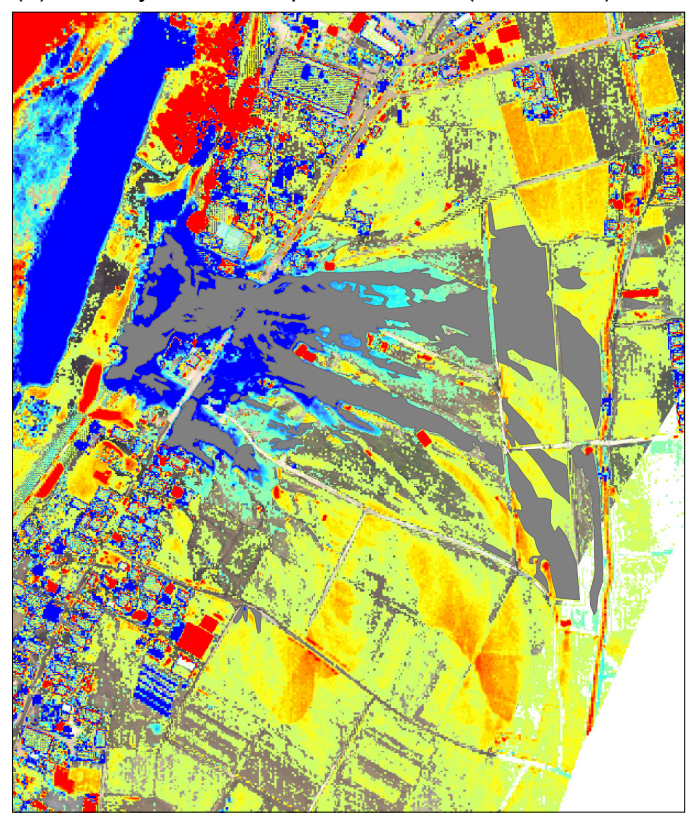

$\mathrm{LoD}=2 \sigma=9.0 \mathrm{~cm}$

Inundated areas in September 2015 (b) September 2015 to December $2015(\sigma=2.0 \mathrm{~cm})$

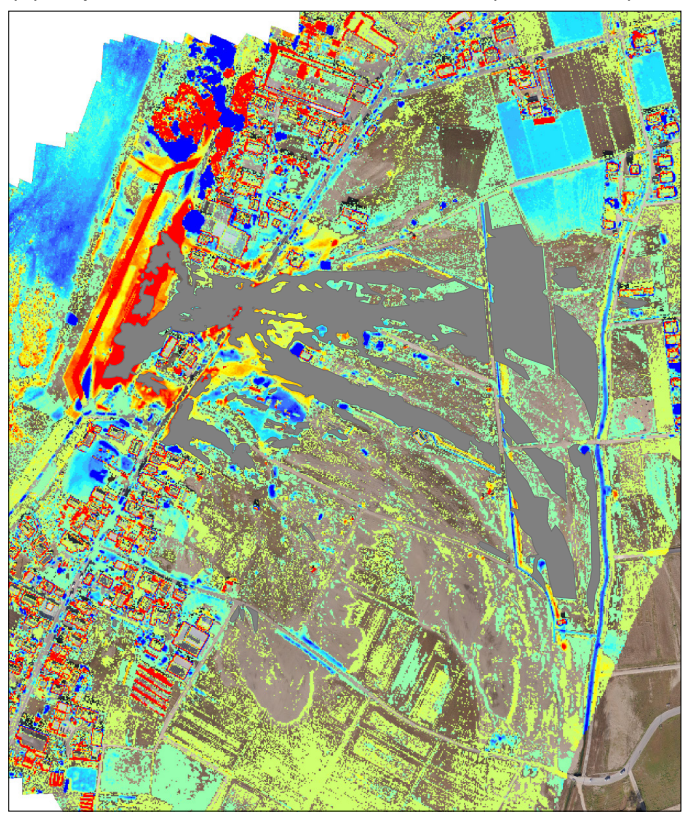

$\mathrm{LoD}=2 \sigma=4.0 \mathrm{~cm}$
Elevation difference $(m)$

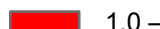
$0.9-1.0$ $0.8-0.9$ $0.7-0.8$ $0.6-0.7$ $0.5-0.6$ $0.4-0.5$ $0.3-0.4$ $0.2-0.3$ LoD -0.2 -LoD - -0.2 $-0.2--0.3$ $-0.3--0.4$ $-0.4--0.5$ $-0.5--0.6$ $-0.6--0.7$ $-0.7--0.8$ $-0.8--0.9$ $-0.9--1.0$ $-1.0-$

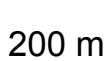

Figure 6. Differential rasters indicating the elevation differences between two successive snapshots after the removal of the systematic error and the adjustment of resolution. (a) The January 2007 DSM subtracted from the September 2015 DSM. Note that erosion near the breached levee was more than $1 \mathrm{~m}$. (b) The September 2015 DSM subtracted from the December 2015 DSM. Note that in DSM areas inundated in September 2015 are masked (see Fig. 8 for the elevation changes in these areas).

viation of the systematic error between the DSMs, namely, $9.0 \mathrm{~cm}$ for the first two dates and $4.0 \mathrm{~cm}$ for the second two dates. The topographic changes less than this limit were neglected in the differential rasters and the volume calculation below. The absolute height of the topography was set to the December 2015 DSM values, the GCPs of which had been accurately measured with real-time kinematic GNSS. The DSMs were processed with the ArcGIS Raster Calculator tool to obtain two differential rasters (Figs. 6, 7). The pixel sizes of both rasters were set to $1 \mathrm{~m}$ for convenience in the volume calculation.

In the inundated areas of the second DSM, the first differential raster represented apparent elevation changes to the water surface, rather than true topographic changes (Fig. 8). The second differential raster showed the water depth in those areas, because inundated areas no longer existed in December 2015. Thus, two sets of differential rasters are shown: one set shows topographic changes (Fig. 6), and the other set shows elevation changes related to the water surface changes (Fig. 7). The inundated areas, which appear light brown because the water was muddy, were determined by examination of the September 2015 aerial photograph (Fig. 3b).

\section{Results and discussion}

\subsection{Comparison of DSMs between January 2007 and September 2015}

The levee breach caused changes to the topography up to 300-500 $\mathrm{m}$ away from the levee: sand splays were deposited, and a crevasse channel appeared; the channel was elongated eastward and then curved southward following the shallow valley, but it was obscure downstream (Fig. 9a, b). The 
(a) January 2007 to September $2015(\sigma=4.5 \mathrm{~cm})$

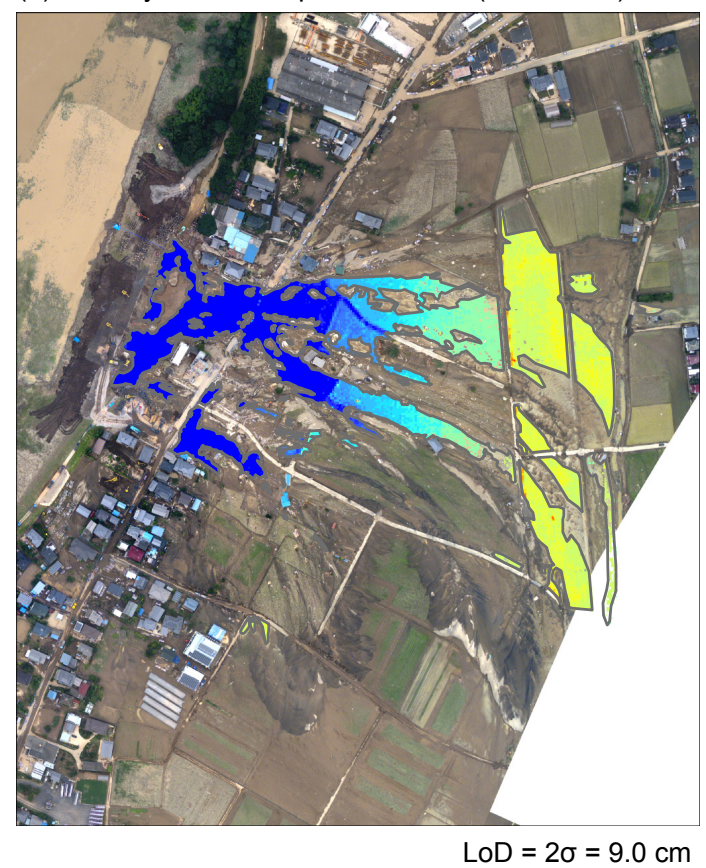

Inundated areas in September 2015 (b) September 2015 to December $2015(\sigma=2.0 \mathrm{~cm})$

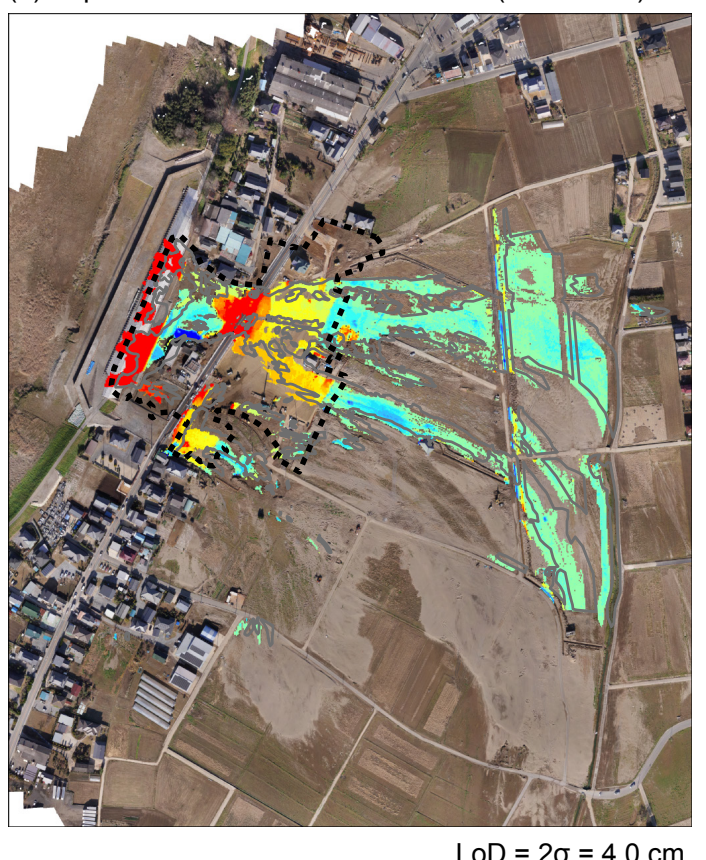

..... Leveled area in December 2015
Elevation

difference $(\mathrm{m})$

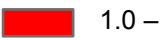

$0.9-1.0$

$0.8-0.9$

$0.7-0.8$

$0.6-0.7$

$0.5-0.6$

$0.4-0.5$

$0.3-0.4$

$0.2-0.3$

LoD -0.2

$-\mathrm{LoD}--0.2$

$-0.2--0.3$

$-0.3--0.4$

$-0.4--0.5$

$-0.5--0.6$

$-0.6--0.7$

$-0.7--0.8$

$-0.8--0.9$

$-0.9--1.0$

$-1.0-$

Figure 7. Differential rasters indicating the elevation differences between two successive snapshots after the removal of the systematic error in the adjustment of resolution in the areas inundated in September 2015. (a) The January 2007 DSM subtracted from the September 2015 DSM. Note that erosion near the breached levee was more than $1 \mathrm{~m}$. (b) The September 2015 DSM subtracted from the December 2015 DSM. The elevation changes within the dashed line do not represent water depths because artificial land filling has been done.

crevasse channel was deep, with distinguishable ditches in its most upstream part, and structures and other artificial features near the breached levee were damaged or destroyed (Fig. 9c).

Buildings and cars, as well as the prefectural road along the levee and other artificial features, were washed away by the flood, and some of them came to rest within the crevasse channel in the study area (Fig. 9d). In the channel behind these obstacles, relatively small, elongated sandy mounds up to $150 \mathrm{~m}$ long were deposited. Sand splays were deposited to the north and south of the obstacles, with clear terminations on their downstream sides (Fig. 9b). The southern splays, 150-200 m long and $100 \mathrm{~m}$ wide, were larger than the northern ones.

Figures $6 \mathrm{a}$ and $7 \mathrm{a}$ show the differential rasters between the DSM before (January 2007) and that 3 days after (September 2015) the flood. Near the levee, the erosional depth exceeded $1 \mathrm{~m}$, decreasing to the east. In the shallow valley formed by the past crevasse channel, however, the topography showed a little aggradation, despite the apparent continuity of the surface seen in the orthophotos (Fig. 3). This aggradation is probably attributable to the presence of crops before the flood and the submergence of the land surface in September 2015. Sand lobe thickness was estimated to be up to $60 \mathrm{~cm}$ in the north and $80 \mathrm{~cm}$ in the south of the research area, except

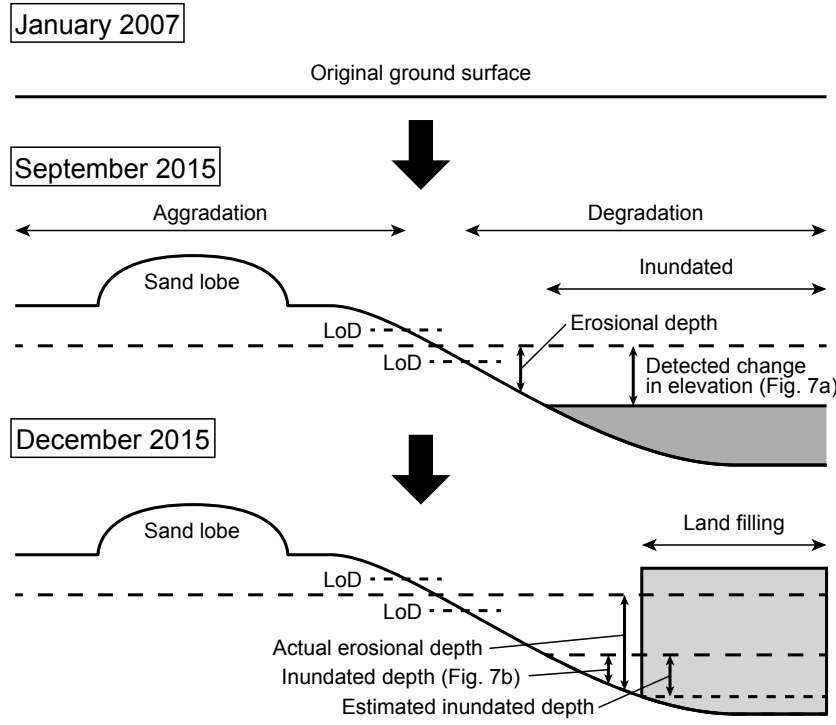

Figure 8. Schematic description of the topographic changes caused by the flood and the later disappearance of inundation water and land filling. Note that elevation changes smaller than the LoD were neglected in the differential rasters and the volume calculations. 

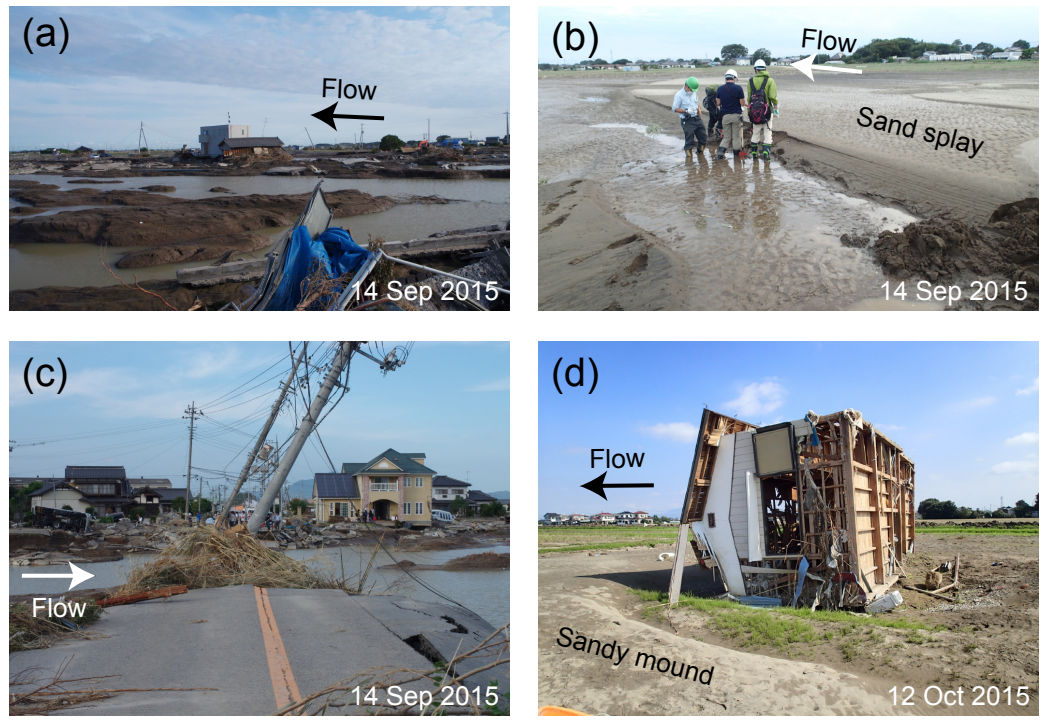

Figure 9. Photos of the study area. (a) Crevasse channel (breach scouring) near the levee. Note the building still standing after the flood in the center of the photo. (b) Sand splay in the southern part of the study area. (c) Damaged prefectural road beside the breached levee. (d) Overturned and transported house. Note the sandy mound in the downstream direction from the house. See Fig. $3 \mathrm{c}$ for the photo locations. Photos were taken by A. Izumida and T. Sugai.

where small sandy mounds had aggraded behind obstacles on the sand splays. Small sandy mounds behind the obstacles with heights of $20 \mathrm{~cm}$ or more are recognizable in the differential raster (Fig. 6a).

In addition to the obvious topographic changes, some subtler changes were detected. For example, aggradation of $10 \mathrm{~cm}$ or more was widely observed beyond both the north and south sand splays, and at some locations the deposition exceeded $50 \mathrm{~cm}$. However, because the systematic error between the DSMs was removed by using the elevation of the paved road, the differential raster represents not only changes caused by the 2015 flood but also changes in the status of the agricultural lands, such as the presence of crops and the soil built up over the course of more than 8 years. Careful evaluation of such changes is needed for a more detailed discussion of flood-related changes.

\subsection{Comparison of DSMs between September 2015 and December 2015}

Three months after the flood (December 2015), the crevasse channel was no longer submerged, and in the orthophoto the areas of sand deposition appeared lighter in color than other, muddier areas (Fig. 3c). In addition to the natural changes, some restoration and repair works were apparent. The breached levee had already been repaired temporarily, the scouring along the prefectural road had been partly filled and the area leveled, and the road had been reopened. In distal areas, there was less modification of the immediate postflood topography, but some changes are visible in both the DSM and orthophoto. For example, crops had grown or been cut in the agricultural lands, and sediments trapped in the canal had been removed, along with the obstacles within the crevasse channel. Numerous wheel tracks on the ground indicate that many vehicles were driven across the study area after the flood, even where marked modification of the topography was not observed. Most of these tracks are no longer visible in the down-sampled SfM-derived DSM (Fig. 5b).

The differential rasters of the DSMs between 3 days after (September 2015) and 3 months after (December 2015) the flood are shown in Figs. 6b and 7b. Significant topographic changes can be observed where restoration works exceeded those completed immediately after the flood. The most remarkable change is the temporary repair of the breached levee, which was raised in height by up to $5.5 \mathrm{~m}(>1 \mathrm{~m}$ in Fig. 6b). The area to the east of the repaired prefectural road seemed mostly flat in the December 2015 DSM and orthophoto (Fig. 3c), but in fact the amount of fill varied between 10 and $60 \mathrm{~cm}$ compared with the original scour topography. In contrast, up to $100 \mathrm{~cm}$ of flood deposits were removed to level the ground in the depositional area near the levee. Several buried canals were restored by excavation, and the sand was heaped on both sides of the canals. Although similar restoration works caused local aggradation or degradation at some points by December 2015, the crevasse splay was left mostly undisturbed, or was modified very little. Thus, during the 3 months after the flood, its features were changed mainly by natural phenomena, except for the reconstruction of the artificial levee and the land filling and leveling along the prefectural road near the breached levee.

The first natural modification was the emergence of the submerged areas of the crevasse channel. The values of the 


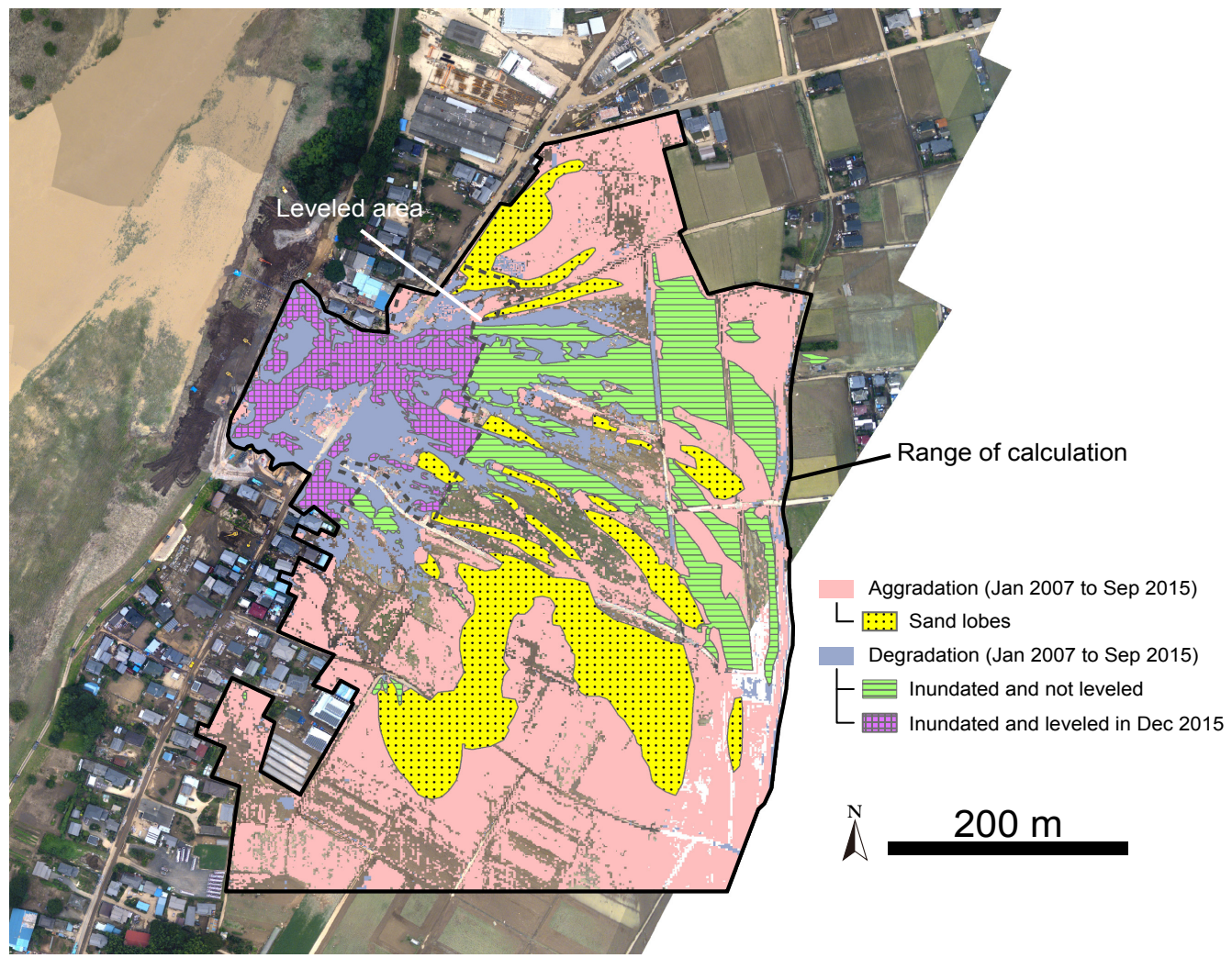

Figure 10. The calculation range used for the volumetric evaluation and the topography types used in the calculation. The areas that were inundated but not leveled in December 2015 (green) contain some aggradational pixels; these pixels were not used in the estimation of water volume, but they were included in the volume gain.

differential raster along the formerly submerged crevasse channel indicate the depth of the pool, because the September 2015 DSM shows mostly the elevation of the water surface in that area (Fig. 7b). Thus, by using two differential rasters, the water depth in the crevasse channel 3 days after the flood can be estimated as well as the total amount of erosion of the alluvial ridge. They show that the water depth was $20-60 \mathrm{~cm}$, and the flood caused erosion of up to $150 \mathrm{~cm}$, with higher values near the levee. In the restored areas along the breached levee, however, the true erosional depth of the scouring, certainly the most significant within the study area, could not be determined from the differential DSMs because the scouring was filled in before the UAV flight was conducted. This is an example of one of the difficulties faced in the investigation of disasters in developed regions.

In the areas that had been covered with muddy sediments, such as beyond the sand splay in the northern part of the study area, shrubs with heights up to $30 \mathrm{~cm}$ grew up, especially around the edge of the splay deposits, after the flood. In natural floodplains, crevasse splay development promotes the formation of new colonies of vegetation (Florsheim and Mount, 2002; Cahoon et al., 2011). It might have been possible to determine the relationship between the topography of the crevasse splay and the location and type of such new growth after the flood from the differential rasters, but such vegetation was removed during the restoration works.

As in previous reports of the topography of crevasse splays (O'Brien and Wells, 1986; Bristow et al., 1999), steep slopes formed at the downstream edges of the crevasse splays in the research area. Three months after their formation, however, the eastern edges of the southern splays had aggraded $10-20 \mathrm{~cm}$, and the western edge of one splay had been lowered by $10 \mathrm{~cm}$, indicating that sand composing the splay had moved eastward. The seasonal winter wind in Japan, the direction of which coincides with the direction of the sand movement and which occasionally exceeds $10 \mathrm{~m} \mathrm{~s}^{-1}$ in speed, combined with the dry wintertime climate of Japan, may have been responsible for these changes.

\subsection{Volumetric evaluations of the topographic changes}

To gain further insight into the 2015 flood event, the volume gains and losses in the research area caused by the 2015 flood were calculated using the two differential rasters. The range of calculation was limited to the area where the topography was clearly affected by the flood in September 2015 (Fig. 10). Although there were some pixels outside the calculation range in which considerable elevation changes were 
Table 3. Results of the volumetric calculations (changes between January 2007 and September 2015).

\begin{tabular}{|c|c|c|c|c|c|c|c|}
\hline & \multicolumn{2}{|c|}{ Aggradation } & \multicolumn{4}{|c|}{ Degradation } & \multirow[b]{2}{*}{$\begin{array}{l}\text { Total changes in the cal- } \\
\text { culation range between } \\
\text { Jan } 2007 \text { and Sep } 2015\end{array}$} \\
\hline & Sand lobes & Total & $\begin{array}{l}\text { Apparent changes } \\
\text { between Jan } 2007 \\
\text { and Sep } 2015\end{array}$ & $\begin{array}{l}\text { Inundated area } \\
\text { (not leveled in } \\
\text { Dec 2015) }\end{array}$ & $\begin{array}{l}\text { Inundated area } \\
\text { (leveled in Dec } \\
\text { 2015) }\end{array}$ & Total & \\
\hline Area $\left(m^{2}\right)$ & 33334 & 137730 & 50168 & 13105 & 12465 & 50168 & 239747 \\
\hline Area $(\%)$ & 13.9 & 57.4 & 20.9 & 5.5 & 5.2 & 20.9 & 100 \\
\hline Volume $\left(\mathrm{m}^{3}\right)$ & 12467 & 37187 & 73948 & 2739 & 3740 & 80426 & -43239 \\
\hline
\end{tabular}

* Estimated value for calculation.

recognized, the status of crops was mainly responsible for those changes rather than the flood deposits and the erosional scours. Areas used for buildings were also excluded from the calculation.

The first differential raster was used to detect aggradational and degradational pixels within the calculation range; those pixels that had smaller values than the LoD of the differential raster were excluded from the calculation (Fig. 10). Then the volume gains and losses were separately calculated using the areas and average values of the pixels.

Distinguishable sand lobes deposited within the area of aggradational pixels were a characteristic feature of the crevasse splay, so their volume and area as a fraction of the entire aggradational pixel area were additionally calculated. In some degradational areas, remaining floodwater in the September 2015 DSM hid the true erosional depth, which could lead to underestimation of the volume loss (Fig. 8). Therefore, the water volume calculated using the differential raster of September 2015 and December 2015 (Fig. 7b), which showed the inundation depth, was added to the degradational area volume losses. However, some inundated areas were covered by plants or sand splay deposits, and the pixels of the differential raster showed an elevation gain, indicating that these areas were not erosive. Therefore, only pixels showing elevation losses on the first differential raster were used to calculate the water volume to be added to the volume loss (Fig. 10). The inundation depth in the area that was leveled during restoration works during the research period could not be estimated with the differential raster. The depth of the scouring was larger near the breached levee, where it reached a maximum of more than $2 \mathrm{~m}$ (Kanto Regional Development Bureau, Ministry of Land, Infrastructure, Transport and Tourism, 2016). Thus, the water depth at the outer edge of the leveled area, which was estimated to be $0.3 \mathrm{~m}$ with the DSMs, was used to estimate the minimum water volume within the leveled area.

The calculation result showed that $78.3 \%$ of the entire calculation range experienced topographic changes larger than the LoD between the January 2007 and September 2015: $57.4 \%$ experienced aggradational changes, and $20.9 \%$ experienced degradational changes (Table 3 ). The total volume gain was $37187 \mathrm{~m}^{3}$, and the volume of the distinguishable sand lobes was estimated to account for $12467 \mathrm{~m}^{3}$ of that gain, which suggests that deposition of the sand lobes was responsible for $33.5 \%$ of the total aggradation by volume, and the sand lobes occupied $24.2 \%$ of the total aggradational area. This result indicates that sand lobe formation might have played a key role in sedimentation during this flood. The volume loss estimated using the first differential raster was $73948 \mathrm{~m}^{3}$, and the additional volume loss calculated from the inundation depth was $6478 \mathrm{~m}^{3}$. Thus, the total erosional volume was estimated to be $80426 \mathrm{~m}^{3}$, which means that the use of another DSM for a later date improved the estimate by $8.1 \%$.

The distribution of the degradational pixels was mostly limited to the area near the breached levee, whereas aggradational pixels were located both around the erosional areas and more distant from the breached levee. The total aggradational area was about 3 times the total degradational area, but the average topographic change of the degradational pixels $(1.60 \mathrm{~m})$ was considerably larger than the aggradational pixel change $(0.27 \mathrm{~m})$. Thus, the total volumetric change in the calculation range was $-43239 \mathrm{~m}^{3}$, which suggests that overall the 2015 flood event was erosive within the research area.

By December 2015, external materials had been imported to the research area for use in post-flood restoration, including reconstruction of the breached levee and leveling of intensively eroded ground near it. The volume of the imported materials was estimated to be at least $20636 \mathrm{~m}^{3}$ from the aggradational pixels within the range of those restoration works on the second differential raster (Table 4). Because the amount of materials transported by other restoration activities and natural processes in the research area was small, this value accounts for most of the topographic changes in the 3 months following the flood. When all volumetric changes due to the flood and the restoration works are taken into account, the research area experienced an estimated volume loss of $22603 \mathrm{~m}^{3}$.

There are some problems with this volumetric estimation. First, the calculated values might be substantially affected not only by topographic changes but also by vegetation and 
Table 4. Results of the volumetric calculations (changes between September 2015 and December 2015).

\begin{tabular}{lll}
\hline & $\begin{array}{l}\text { Leveled area be- } \\
\text { tween Sep and } \\
\text { Dec 2015 }\end{array}$ & $\begin{array}{l}\text { Total changes in the } \\
\text { calculation range } \\
\text { between Sep and } \\
\text { Dec 2015 }\end{array}$ \\
\hline Area $\left(\mathrm{m}^{2}\right)$ & 20331 & 239747 \\
Area $(\%)$ & 8.5 & 100 \\
Volume $\left(\mathrm{m}^{3}\right)$ & 20636 & -22603 \\
Average change $(\mathrm{m})$ & 1.02 & -0.09 \\
\hline
\end{tabular}

buildings. For example, the crops in the research area elevated the DSM in September 2015, leading to overestimation of the volume gain, and destroyed buildings in the erosive reaches might have caused overestimation of the apparent eroded volume because destroyed building were not considered. Second, although water depth in inundated areas could be estimated using an additional DSM, it was not possible to determine the water depth in the leveled area in December 2015. This drawback could be overcome by more frequent acquisition of topographic data, which can be easily done with a UAV and SfM analysis. Third, the simple subtraction procedure used to generate the differential rasters assumed that the contact between the original ground surface before the flood and the flood deposits above was non-erosional. However, Matsumoto et al. (2016) reported that this boundary had clear erosional characteristics. Therefore, the calculated volumetric gain might be underestimated. Moreover, any deposition that may have occurred in the pixels detected as degradational was also neglected. Field observations could help correct these uncertainties, but it would be difficult to measure thicknesses of eroded beds. Nevertheless, quantitative information derived from a time series of topographic data can fairly represent the 3-D architecture of a crevasse splay and may enable us, following flood disasters, to estimate the volume of deposits that need to be removed and, conversely, the amount of materials needed to reconstruct embankments or to use for land filling. In particular, the volumetric contributions of sand lobes and land filling to the topography calculated in this study could be used for such applications.

\subsection{Recording of landforms with low preservation potential by using UAV-SfM and lidar in combination}

In the context of disaster management, high-resolution photos and videos taken by UAVs can help in the development of strategies for dealing with emergencies (Ezequiel et al., 2014; Erdelj and Natalizio, 2016). Another UAV "eye", namely, topographic data obtained by SfM photogrammetry, can also be informative, particularly if acquired immediately after the occurrence of a disaster. Of course, pre-flood topo- graphic data are necessary to quantify the degree of erosion and deposition. In Japan, open-access lidar data with a resolution of $5 \mathrm{~m}$ covering the whole country except for some remote areas, available from the Geospatial Information $\mathrm{Au}$ thority of Japan (Sato et al., 2010), can be used for comparison with data obtained after disasters. For example, Saito et al. (2016) utilized a combination of UAV-SfM topographic data obtained after a heavy rainfall in the mountains of southeastern Japan and available pre-hazard lidar data to estimate sediment yields of landslides. This study and that of Saito et al. (2016) both took advantage of the availability of UAVs, which because of their low cost and flexible operation can be effectively used to obtain topographic measurements for determining, in combination with past lidar data, topographic changes related to sudden events.

UAVs can easily be used to obtain additional topographic data on successive dates to produce, by SfM photogrammetry analysis, "4-D" topographic models, that is, 3-D models that show the evolution of the measurement objectives over time (Gomez and Purdie, 2016). This study achieved this objective at a very primitive level by using DSMs obtained at three different times to estimate floodwater inundation depth and shrub growth and for volumetric estimation of post-flood topographic changes. A similar multitemporal analysis of topography would be possible in other areas in Japan, and anywhere else in the world where extensive topographic measurements have been made; thus, this method is expected to become applicable to more and more regions as topographic data become more available.

Another approach to the quantification of morphological changes is archival photogrammetry, that is, the use of SfM methods with aerial photographs taken in the past (Bakker and Lane, 2016). Although data sources may be limited in number and resolution, this approach can be used for the reconstruction of historical events and thus can extend the timeline of topography backwards to the period before lidar data became available. The accumulation of knowledge about the nature of hazardous earth surface processes occurring both at present and in the past is expected to help us to mitigate the adverse consequences of future disasters suffered by people and human society.

\section{Conclusions}

Repeated topographic measurements by UAV-SfM photogrammetry and lidar, with a horizontal resolution on the order of $10^{-2}$ and $10^{0} \mathrm{~m}$, respectively, were successfully used to quantify topographic changes on a floodplain caused by the 2015 flood of the Kinu River, including the formation of a crevasse splay and both natural and artificial post-flood modifications. All three topographic data sets used in this study were surface models, but in most of the research area they represented the ground elevation because there were few buildings and little vegetation except for agricultural crops. 
However, these objects might have considerable effects on volumetric analyses.

The horizontal accuracy of the DSMs estimated from the positions of building edges showed that the difference in resolution of the DSMs determined the accuracy of the comparisons made by raster calculations. The systematic error between DSMs was assumed to be merely the average of the elevation differences at several selected points. In fact, almost all parts of the prefectural road, which were assumed to be stable throughout the study period, were shown to experience small elevation changes (less than $10 \mathrm{~cm}$ ) in both comparison pairs: January 2007 versus September 2015 and September 2015 versus December 2015. It any case, it may be inappropriate to compare UAV-SfM-derived DSMs with very high resolution with lidar-derived DSMs, which have a relatively low resolution, because the former surface models show trivial relief due to wheel tracks, plants, debris, and so on. Down-sampling of the UAV-SfM-derived DSMs to $1 \mathrm{~m}$ resolution, to match that of the lidar-derived DSMs, removed these local topographic fluctuations and facilitated comparison with the surface models based on lidar measurements. Elevation differences on the order of $10^{-1} \mathrm{~m}$ were detectable between pairs of DSMs after the removal of the systematic error and the adjustment of the resolution. However, care is needed to account for environmental changes due differences in the time of acquisition, such as vegetation growth and ground modification by humans.

The topography of the crevasse splay was characterized by intensive erosion near the breached levee and deposition of flood sediments, especially lobe-shaped sand mounds, occupying $33.5 \%$ of the total aggradational area, around the erosional areas. Volumetric analysis indicated that, although the degradational pixel area was about one-third the aggradational pixel area, the estimated volume loss was more than twice the volume gain; as a result, overall there was a volume loss of $43239 \mathrm{~m}^{3}$ due to the event in the research area. Repeated measurement of the topography allowed quantification of post-formation modifications of the crevasse splay. With surface models, not only changes to the topography itself but also changes in vegetation and inundation water depth, as well as artificial modifications due to restoration and repair, could be quantified. Estimation of the true erosional depth in the inundated areas by using a third DSM, obtained after the floodwaters had receded, improved the estimation of the total volume loss by $8.1 \%$. The reconstruction of the breached levee and the artificial leveling of intensively eroded ground near it were major causes of topographic changes after the flood, and those activities restored $25.6 \%$ of the volume eroded by the flood.

However, there are three main issues with the volume estimation in this study. First, effect not due to topography but to buildings and agricultural crops need to be accounted for. Second, a lack of topographic data for the entire crevasse splay limited the accuracy of the estimation; the erosion depth in some areas could not be estimated because of restoration works. Finally, the estimation assumed that the contact between the flood deposits and the original surface was non-erosional, but that assumption is not validated. Use of topographic models from which buildings and vegetation have been removed; repeated measurement of rapidly changing topography at appropriate intervals, which can easily be achieved by using the UAV-SfM protocol; and the use of field observations along with remotely obtained data would improve the estimation.

Data acquired speedily and at low cost $(2 \mathrm{~h}$ in the field covered $0.793 \mathrm{~km}^{2}$ in this study) by UAV can be effectively used, particularly in combination with lidar data obtained beforehand, to capture natural-disaster-related topographic changes, particularly in inhabited regions where they have low preservation potential because the affected topography is likely to be restored soon after the disaster. Because river floods and the consequent formation of crevasse splays occur in floodplains around the world, the accumulation of similar studies will promote our understanding of the splay formation process and will also enable damages caused by such flooding to be mitigated. To achieve this goal, however, an extensive lidar database must be prepared and maintained to enable quantification of topographic changes due to floods and other disasters by UAV-SfM photogrammetry.

Data availability. The aerial photos taken by the UAV and the SfMprocessed DSM are not publicly available because the authors are conducing further analyses. The post-flood lidar and orthophotos were provided to the authors with special permission from Aero Asahi Corp. The pre-flood lidar data and orthophotos are available with permission from the Kanto Regional Development Bureau, Ministry of Land, Infrastructure, Transport and Tourism of Japan.

Author contributions. AI undertook the processing and interpretation of the data and the preparation of the manuscript with contributions from all co-authors. SU undertook the data acquisition with the UAV and the SfM processing. TS designed the research and gave final approval of the article.

Competing interests. The authors declare that they have no conflict of interest.

Special issue statement. This article is part of the special issue "The use of remotely piloted aircraft systems (RPAS) in monitoring applications and management of natural hazards". It is not associated with a conference.

Acknowledgements. We gratefully thank Hiroshi Kobayashi of Aero Asahi Corporation for providing the processed DSM derived from the post-flood lidar data and the orthophotos acquired in September 2015. This study was financially supported by JSPS 
KAKENHI grant number JP26282078. We would like to thank the one anonymous reviewer and Yuichi S. Hayakawa for their constructive comments, which helped to improve the manuscript. Language editing was provided by Susan Duhon and Bob Wathen of ELSS, Inc.

Edited by: Yuichi S. Hayakawa

Reviewed by: Yuichi S. Hayakawa and one anonymous referee

\section{References}

Bakker, M. and Lane, S. N.: Archival Photogrammetric Analysis of River-Floodplain Systems Using Structure from Motion (SfM) Methods, Earth Surf. Proc. Land., 42, 1274-1286, https://doi.org/10.1002/esp.4085, 2016.

Barredo, J. I.: Major flood disasters in Europe: 1950-2005, Nat. Hazards, 42, 125-148, https://doi.org/10.1007/s11069-0069065-2, 2007.

Berz, G., Kron, W., Loster, T., Rauch, E., Schimetschek, J., Schmieder, J., Siebert, A., Smolka, A., and Wirtz, A.: World map of natural hazards - a global view of the distribution and intensity of significant exposures, Nat. Hazards, 23, 443-465, https://doi.org/10.1023/A:1011193724026, 2001.

Bristow, C. S., Skelly, R. L., and Ethridge, F. G.: Crevasse splays from the rapidly aggrading, sand-bed, braided Niobrara River, Nebraska: Effect of base-level rise, Sedimentology, 46, 10291047, https://doi.org/10.1046/j.1365-3091.1999.00263.x, 1999.

Cahoon, D. R., White, D. A., and Lynch, J. C.: Sediment infilling and wetland formation dynamics in an active crevasse splay of the Mississippi River delta, Geomorphology, 131, 57-68, https://doi.org/10.1016/j.geomorph.2010.12.002, 2011.

Croke, J., Todd, P., Thompson, C., Watson, F., Denham, R., and Khanal, G.: The use of multi temporal LiDAR to assess basinscale erosion and deposition following the catastrophic January 2011 Lockyer flood, SE Queensland, Australia, Geomorphology, 184, 111-126, https://doi.org/10.1016/j.geomorph.2012.11.023, 2013.

Erdelj, M. and Natalizio, E.: UAV-Assisted Disaster Management: Applications and Open Issues, 9th Int. Work. Wirel. Sensor, Actuator Robot Networks (WiSARN 2016), 2016.

Ezequiel, C. A. F., Cua, M., Libatique, N. C., Tangonan, G. L., Alampay, R., Labuguen, R. T., Favila, C. M., Honrado, J. L. E., Canos, V., Devaney, C., Loreto, A. B., Bacusmo, J., and Palma, B.: UAV aerial imaging applications for post-disaster assessment, environmental management and infrastructure development, 2014 Int. Conf. Unmanned Aircr. Syst., 274-283, https://doi.org/10.1109/ICUAS.2014.6842266, 2014.

Feng, Q., Liu, J., and Gong, J.: Urban flood mapping based on unmanned aerial vehicle remote sensing and random forest classifier-A case of yuyao, China, Water (Switzerland), 7, 14371455, https://doi.org/10.3390/w7041437, 2015.

Florsheim, J. L. and Mount, J. F.: Restoration of floodplain topography by sand-splay complex formation in response to intentional levee breaches, Lower Cosumnes River, California, Geomorphology, 44, 67-94, https://doi.org/10.1016/S0169555X(01)00146-5, 2002.
Gebica, P. and Sokolowski, T.: Sedimentological interpretation of crevasse splays formed during 1997 flood in the Vistula River Valley (South Poland), Ann. Soc. Geol. Pol., 71, 53-62, 2001.

Gomez, C. and Purdie, H.: UAV- based Photogrammetry and Geocomputing for Hazards and Disaster Risk Monitoring - A Review, Geoenvironmental Disasters, 3, 23, https://doi.org/10.1186/s40677-016-0060-y, 2016.

Inoue, H., Uchiyama, S., Suzuki, H., and Risk, D.: Multicopter Aerial Photography for Natural Disaster Research, Report of the National Research Institute for Earth Science and Disaster Prevention, 81, 61-98, 2014 (in Japanese with English abstract).

Iseya, F., Ikeda, H., and Mikami, Y.: Topographic changes at levee breached area of the Kokai River in August, 1981, Bull. Environ. Res. Ctr., Univ. of Tsukuba, 6, 117, 1982 (in Japanese).

James, M. R. and Robson, S.: Mitigating systematic error in topographic models derived from UAV and ground-based image networks, Earth Surf. Proc. Land., 39, 1413-1420, https://doi.org/10.1002/esp.3609, 2014.

Japan Meteorological Agency: Natural phenomenon report for disasters 1, available at: http://www.jma.go.jp/jma/kishou/books/ saigaiji/saigaiji_2015/saigaiji_201501.pdf (last access: 8 May 2017), 2015 (in Japanese).

Joso City: Inspection report on actions for the 2015 flood of the Kinu River in Joso City, available at: http://www.city.joso.lg.jp/ ikkrwebBrowse/material/files/group/6/kensyou_houkokusyo.pdf (last access: 8 May 2017), 2016 (in Japanese).

Kanto Regional Development Bureau, Ministry of Land, Infrastructure, Transport and Tourism: Report on flood damages and restoration status for the September 2015 KantoTohoku Heavy Rainfall, available at: http://www.ktr.mlit.go.jp/ ktr_content/content/000633805.pdf (last access: 8 May 2017), 2015 (in Japanese).

Kanto Regional Development Bureau, Ministry of Land, Infrastructure, Transport and Tourism: Reconnaissance report of Kinugawa Levee Investigation Committee, available at: http://www.ktr.mlit. go.jp/ktr_content/content/000643703.pdf (last access: 8 May 2017), 2016 (in Japanese).

Kundzewicz, Z. W., Hirabayashi, Y., and Kanae, S.: River Floods in the Changing Climate-Observations and Projections, Water Resour. Manag., 24, 2633-2646, https://doi.org/10.1007/s11269009-9571-6, 2010.

Matsumoto, D., Sawai, Y., Yamada, M., Namegaya, Y., Shinozaki, T., Takeda, D., Fujino, S., Tanigawa, K., Nakamura, A., and Pilarczyk, J. E.: Erosion and sedimentation during the September 2015 flooding of the Kinu River, central Japan, Sci. Rep., 6, 34168, https://doi.org/10.1038/srep34168, 2016.

Ministry of Land, Infrastructure, Transport and Tourism Japan: Publishing the damage amount (final values) by flood disasters in 2015, available at: https://www.mlit.go.jp/common/001176247. pdf, last access: 8 May 2017 (in Japanese).

Nagumo, N., Ohara, M., Kuribayashi, D., and Sawano, H.: The 2015 Flood Impact due to the Overflow and Dike Breach of Kinu River in Joso City, Japan, J. Disaster Res., 11, 1112-1127, https://doi.org/10.20965/jdr.2016.p1112, 2016.

Nelson, S. A. and Leclair, S. F.: Katrina's unique splay deposits in a New Orleans neighborhood, GSA Today, 16, 4-10, https://doi.org/10.1130/GSAT01609A.1, 2006.

Ninfo, A., Mozzi, P., and Abbà, T.: Integration of LiDAR and cropmark remote sensing for the study of fluvial 
and anthropogenic landforms in the Brenta-Bacchiglione alluvial plain (NE Italy), Geomorphology, 260, 64-78, https://doi.org/10.1016/j.geomorph.2015.11.006, 2016.

O'Brien, P. E. and Wells, A. T.: A small, alluvial crevasse splay, J. Sediment. Res., 56, 876879, https://doi.org/10.1306/212F8A71-2B24-11D78648000102C1865D, 1986.

Pineux, N., Lisein, J., Swerts, G., Bielders, C. L., Lejeune, P., Colinet, G., and Degré, A.: Can DEM time series produced by UAV be used to quantify diffuse erosion in an agricultural watershed?, Geomorphology, 280, 122-136, https://doi.org/10.1016/j.geomorph.2016.12.003, 2016.

Sadakata, N.: Formation of the Lower Kinu River Floodplain, Geographical Sciences (Chiri Kagaku), 18, 13-22, 1971 (in Japanese with English abstract).

Saito, H., Uchiyama, S., Obanawa, H., and Hayakawa, Y. S.: Sediment yields triggered by heavy rainfall in July 2012 at Aso Volcano: application of high-definition topography data using unmanned aerial vehicles and structure-from-motion multi-view stereo photogrammetry, Geographical Review of Japan Series A, 89, 347-359, 2016 (in Japanese with English abstract).

Sato, H., Iwahashi, J., Koarai, M., Kamiya, I., and Komuro, K.: Preparation of high-resolution digital elevation models by the Geospatial Information Authority of Japan and their applications to geographic information analysis, Transactions, Japanese Geomorphological Union, 31, 359-382, 2010 (in Japanese with English abstract).
Tamminga, A. D., Eaton, B. C., and Hugenholtz, C. H.: UASbased remote sensing of fluvial change following an extreme flood event, Earth Surf. Proc. Land., 40, 1464-1476, https://doi.org/10.1002/esp.3728, 2015a.

Tamminga, A. D., Hugenholtz, C., Eaton, B., and Lapointe, M.: Hyperspatial remote sensing of channel reach morphology and hydraulic fish habitat using an unmanned aerial vehicle (UAV): a first assessment in the context of river research and management, River Res. Appl., 31, 379-391, https://doi.org/10.1002/rra.2743, 2015b.

Tarolli, P.: High-resolution topography for understanding Earth surface processes: Opportunities and challenges, Geomorphology, 216, 295-312, https://doi.org/10.1016/j.geomorph.2014.03.008, 2014.

Wierzbicki, G., Ostrowski, P., Mazgajski, M., and Bujakowski, F.: Using VHR multispectral remote sensing and LIDAR data to determine the geomorphological effects of overbank flow on a floodplain (the Vistula River, Poland), Geomorphology, 183, 7381, https://doi.org/10.1016/j.geomorph.2012.06.020, 2013.

Yoshimura, K.: Statistical analysis of the heavy rain triggering the flood of the Kinu River, in: Report on disaster investigations in the Kanto region for the September 2015 Kanto-Tohoku Heavy Rainfall, Joint Research Group in the Kanto Region of Japan Society of Civil Engineering and The Japanese Geotechnical Society for the September 2015 Kanto-Tohoku Heavy Rainfall, 18-20, available at: http://committees.jsce.or.jp/report/node/118 (last access: 8 May 2017), 2016 (in Japanese). 